\title{
„Globalus karas su terorizmu“: iš naujo atrasta sukilimo ir kontrsukilimo teorija
}

Dažnai naudojamas terminas "globalinis karas su terorizmu“ yra tapęs ịprastu Vakaru pasaulio politinių lyderiu, akademiku ir analitikų leksikoje. Tačiau jis sukelia nemažai prieštaravimu bei interpretaciju, kurie nepadeda suvokti vykstančio konflikto esmès ir dinamikos. Pirmiausia reikia pripažinti, jog tai yra karas, kuriame konfliktuojančios pusės siekia politinių tikslų ir naudoja prievartą jiems pasiekti. Turint omeny, kad viena iš šiu pusiu yra nevalstybinis veikëjas, produktyviausias kelias yra bandyti taikyti seniai egzistuojančią ir gerai išplètotą sukilimo ir kontrsukilimo teoriją, iki šiol naudota tik konfliktui valstybės viduje tarp vyriausybės ir sukilèlių. Didele dalimi „globalinio karo su terorizmu" strategine logika atitinka šios teorijos principus, tačiau juos taikyti reikia šiai teorijai neịprastoje aplinkoje - tarptautinès sistemos lygyje, su globalinès ir transnacionalinės dimensijos dikuotuojamais savitais iššūkiais.

\section{Ivadas}

1999 m. pavasarį šio straipsnio autorius dalyvavo Viltono Parko konferencijoje Jungtinëje Karalystëje. Kaip ir iprasta tuo metu, pagrindinė gvildenta tema buvo transatlantiniai santykiai ir ju perspektyvos. Visi dalyviai - saugumo politikos ekspertai, akademikai, diplomatai, kariškiai - beveik vienbalsiai sutarè, kad, pasibaigus Šaltajam karui ir nelikus bendros visuotinės grèsmès, transatlantinis Aljansas buvo atsidūręs tam tikrame strateginiame vakuume, kurio neužpildė nei Balkanų karai, nei demokratinės erdvės plètra į Rytus. Tačiau vieno istorijos profesoriaus mintis patraukè bent jau kai kurių dalyvių dèmesį. Kaip ir visi istorikai, sugebantys matyti platesnę chronologinę perspektyvą nei dabarties iššūkių valdomi saugumo politikos ekspertai, jis išsakẻ labai toliaregišką, netgi pranašiška, nuostatą. Anot jo, remiantis istorijos cikliškumo principu, šiuolaikinis pasaulis gyveno ne pokario laikotarpiu, o tarpukariu - laikotarpiu tarp Šaltojo karo ir kažkokio kito karo, kurio priežasčiu, dalyvių ir bruožų mes turbūt net nenumanome.

Praejus vos dvejiems metams, ši mintis pasitvirtino su kaupu. $2001 \mathrm{~m}$. rugsèjo 11-oji akimirksniu pakeitè pasaulio strateginį peizažą. Radikali islamo

\footnotetext{
* Tomas Jermalavičius - Baltijos gynybos koledžo dekanas. Adresas: Riia 12, 51013 Tartu, Estija, tel.: +372-7176039, el. paštas: tomas.jermalavicius@bdcol.ee.
} 
grupuotė $\mathrm{Al}$ Qaeda mete iššūki pasaulio hegemonui - Jungtinėms Amerikos Valstijoms - atakuodama Niujorke ir Vašingtone taikinius, simbolizuojančius hegemono ekonominę ir karinę galią. Tos dienos šokas ir poveikis JAV užsienio politikai ir strategijai dažnai prilyginamas Perl Harborui. Skirtumas tas, jog teroristinės atakos, surengtos pačioje Amerikos širdyje, transliuotos visam pasauliui televizijos ir interneto kanalais, sukèlè beveik trijų tūkstančiu, daugiausiai civiliu, žmonių mirtį ir atnešè milijardus dolerių nuostolių. Tai neprecedentinis îvykis ir ypač dèl to, jog jį metẻ ne kita valstybè, o nevalstybinè grupuotè.

JAV atsako mastai ir užmojis ne ką mažesni. Prezidentas Georgas W. Bushas paskelbè kara, kuris tapo visiems žinomas kaip „globalinis karas su terorizmu“: įvardyti priešai, sutelkti sajungininkai, ispèti svyruojantys ir abejojantys, nustatyti ideologiniai parametrai, sustiprintos valstybės policinės ir sekimo funkcijos, ženkliai padidintas karinis biudžetas ir pradèti karo veiksmai. Šio konflikto kontekste praejjusio amžiaus paskutinis dešimtmetis iš tikrujų atrodo kaip tarpukaris. Tiesa, taika tuo laikotarpiu buvo tokia pat iliuzija daugelyje pasaulio regionu, kaip ir bet kuriuo kitu metu, netgi Vakaru valstybems, kurios praktikavo "humanitarinės intervencijos" doktriną ir siunte savo karius i „,karštuosius" pasaulio taškus. Tačiau bent jau tikètasi, jog globalinio masto konfliktas, kaip kad Pirmasis ir Antrasis pasauliniai karai arba Šaltasis karas, liko tolima ir labiau teorinė galimybè. Jei ir buvo spèliojimų bei prognoziu, tai jie daugiau koncentravosi į Kiniją, kaip kylančią galią. Tačiau Osama bin Ladenas, Al Qaeda lyderis, įrodè, jog pakanka religinio fanatizmo dozės, gero planavimo, vaizduotès, keliu šimtų tūkstančių dolerių bei tinkamo politinio, socialinio ir strateginio konteksto, kad būtų išprovokuotas naujas pasaulinis konfliktas.

Beveik visi sutaria, kad tai kitoks konfliktas, nei prieš tai buvę, kaip ir Šaltasis karas buvo kitoks nei du pasauliniai karai. Diskusijos dèl jo pobūdžio vis dar tęsiasi. Kai kurie ekspertai teigia, kad tai iš viso nèra karas, todèl ir karinè galia čia neturi jokio ryškesnio vaidmens. Kiti atmeta jo ambicingą mastą (karas prieš „,terorizmą“), teigdami, jog tai tėra retorika, kaip ir „,karas su narkotikais“. Treti studijuoja visus įmanomus šaltinius apie kovą su terorizmu, siekdami suteikti pagrindą efektyviai strategijai, bet daugiau ar mažiau ignoruodami politinę ir ideologinę konflikto dimensijas. Tačiau pastaruoju metu atsiranda vis daugiau šaltiniu, kurie nagrinejja "globalinį karą su terorizmu" pasitelkdami sukilimo ir kontrsukilimo (angl. insurgency and counter-insurgency) teoriją. Iki šiol remdamiesi šia teorija analizavo ginkluotą konfliktą valstybės viduje. „Globalinio karo su terorizmu“ atveju teorijos taikymas perkeliamas į aukštesni, tarptautinès sistemos, lygmenị. Tam tikra prasme tai yra logiška praëjusio amžiaus pabaigoje išpopuliarëjusių teziu, jog tarptautinëje sistemoje vis didesnę įtaką turi nevalstybiniai veikejjai ir jog didelio tarpvalstybinio karo grèsmè yra nedidelè, jungtis ir tąsa. Tam tikru metu, nevalstybiniams veikëjams igyjant priëjimą prie vis įvairesnių galios šaltiniu, turëjo įvykti konfliktas su pagrindiniais esamos pasaulio tvarkos garantais - valstybèmis. Iššūkis atëjo $\mathrm{Al}$ Qaedos organizacijos pavidalu ir buvo mestas hegemoninei valstybei-Jungtinems Valstijoms, kuriu politinè, ekonominè, karinè ir kultūrinė galia būtent ir palaiko šiuolaikinę pasaulio tvarką. Natūralu, kad teorija, kuri paaiškina ginkluotą konfliktą valstybės viduje tarp politinės sistemos garanto-vyriausybės - ir nevyriausybiniu grupiu, tampa patraukliu modeliu tarptautinès sistemos lygmenyje. 
Šio straipsnio tikslas yra, pasitelkus pagrindinius sukilimo ir kontrsukilimo teorijos postulatus, apibūdinti "globalinio karo su terorizmu" logiką ir, anot Klausewitzo, "gramatiką". Pagrindinis klausimas yra tai, kaip remiantis minèta teorija galima interpretuoti šiuolaikinį konfliktą tarptautinèje sistemoje bei numatyti jo galimas pasekmes. Straipsnis nesiekia gilintis i tarptautinès sistemos pobūdi ar konflikto veikëju veiksmus bei paskirus ịvykius. Visas demesys yra sutelktas į sukilimo ir kontrsukilimo teorijos adekvatumą "globalinio karo su terorizmu" kontekste pačiais bendriausiais bruožais. Pasirinktas strateginis naratyvas, kuriame neskiriama vietos taktikai ar operacijoms, bet gilinamasi i pačias svarbiausias paraleles tarp sukilimo ir kontrsukilimo valstybės viduje bei "globalinio karo su terorizmu“. Pirmojoje darbo dalyje gan išsamiai apžvelgiama litertūra ir pagrindinès sukilimo ir kontrsukilimo, kaip vieno iš karo tipu, teorijos tezės. Antroji darbo dalis skirta "globalinio karo su terorizmu“" kaip globalinio sukilimo ir kontrsukilimo, analizei.

\section{Sukilimo ir kontrsukilimo teorija}

Sukilimo ir kontrsukilimo teorija nėra teorija griežtaja prasme. Tai daugiau viena iš karo studijų sričių, nagrinëjančių konkretų ginkluoto konflikto tipą, būtent tarp vyriausybès ir ginkluotų sukilèliu. Šios srities diskusijų užuomazgu Vakarų strateginëje mintyje galima atrasti tiek to paties Karlo von Klausewitzo veikale, tiek kito klasikinès strateginès minties atstovo, barono Antoine Henri de Jominio knygoje „Karo menas“, kur jis komentavo ispanu partizanini pasipriešinimą Napoleono okupacijai. Platesnių šios temos studiju pasirodė XX a. pradžioje. Iš šio laikotarpio geriausiai žinomas yra Thomas Edwardas Lawrence'as, arba Arabijos Lawrence'as, britų karininkas, kuris aprašè savo pastebẻjimus iš arabų sukilimo prieš kolonistus 1916-1918m. knygoje „Septyni išminties ramsčiai“ ("Seven Pillars of Wisdom") bei jos sutrumpintame variante "Sukilimas dykumoje“ (, Revolt in the Desert"). Ne mažiau prie sukilimo ir kontrsukilimo teorijos kūrimo prisidejjo ir C. E. Callwellas, kitas britų karininkas, turèjęs didelę patirtị iš kolonijinių karų ir sukilimų malšinimo Pietų Afrikoje ir Indijoje bei parašęs klasikinį veikalą „Maži karai: ju principai ir praktika“ („Small Wars: Their Principles and Practice"). XX a. literatūros apie sukilimus ir kontrsukilimus gausa didëjo proporcingai šio konflikto tipo ",populiarējimui“, pradedant sukilimais prieš kolonijines galybes ir baigiant ideologiniais konfliktais tarp komunistų ir antikomunistų judejjimų. Mao ir Che Guevara yra turbūt geriausi žinomi sukilimo praktikai ir teoretikai iš šio laikotarpio, nors egzistuoja ir daugybè kitų autoriu, pradedant airiu Michaelu Collinsu bei vietnamiečiu Vo Nguyen Giapu ir baigiant brazilu Carlosu Marighella. Šiuolaikinès sukilimo ir kontrsukilimo teorijos modifikacijos atsispindi tokių autoriu, kaip Williamas 
S. Lindas arba Johnas Arquilla, konceptuose - „ketvirtos kartos karas“ (4th Generation Warfare, arba $4 G W)^{1}$ bei "tinklakaris“ (netwar).

\subsection{Terminologijos problema: ar sukilimas yra karas?}

Nagrinejjant minètų autorių literatūrą, krinta į akis gausybė šios srities terminų. Tačiau visi jie nusako iš esmès tą patị sukilimo ir kontrsukilimo reiškini, tik skirtingu lygiu arba akcentuojant skirtingas jo dimensijas ar bruožus: partizaninis karas (guerilla warfare - akcentuojama taktika), ginkluotas pasipriešinimas (akcentuojamas smurtinis elementas), asimetrinis karas (akcentuojami galios ir metodų skirtumai tarp kovojančių pusių), „mažas karas“, revoliucinis karas ir pan. Abejonių nèra dèl vieno - sukilimas ir kontrsukilimas yra karas. Atrodytu, akivaizdus ir netgi keistas pastebèjimas. Tačiau valstybės ir visuomenés dažnai atsisako traktuoti ši konfliktą kaip karą, kol netampa vèlu. Lygiai ta pati problema yra iškilusi "globalinio karo su terorizmu“ diskurse, daugelis analitiku kvestionuoja termino „karas“ vartojimą. Štai Jamesas Carrollas aiškina, jog „,karas su terorizmu nèra karas, nes, nors mes turime priešą, tik raumenimis besiremiantis Pentagonas nepasiūlo jokių tinkamų puolimo priemonių“2. Panašiai teigiama, kad atsakas ị Al Qaedos iššūkị yra daugiau policijos ir žvalgybos tarnybu, o ne kariuomeniu funkcija ${ }^{3}$. Kaip pamatysime vèliau, šioje išvadoje yra dalis tiesos, tačiau ne dèl to, jog sukilimas ir kontrsukilimas nèra karas.

Klasikinis karo apibrėžimas, netgi tam tikras testas, yra Karlo von Klausewitz karo konceptas. Pasak jo, karas yra ,jejgos aktas, kuriuo siekiama priversti oponentą vykdyti ne savo valią “" . Drauge karas yra "politikos tąsa, tik kitomis priemonėmis “5. Sukilimo ir kontrsukilimo esmẻ būtent ir yra jëgos, smurto naudojimas politiniais tikslais, siekiant priversti oponentus vykdyti svetimą valią. Anot Steveno Metzo ir Raymondo Milleno, „sukilimas yra strategija, kurios imasi grupès, negalinčios pasiekti savo politinių tikslų konvencinėmis priemonėmis ar staigiai perimant valdžią. Sukilimą charakterizuoja tam tikrą laiką trunkantis, asimetrinis smurtas, sudetingos geografijos išnaudojimas, psichologinis karas ir politinè mobilizacija - visa tai, kas padeda sukilèliams išsilaikyti ir galiausiai pakeisti jègų balansą savo naudai“ ${ }^{\prime \prime}$. Akivaizdu, jog sukilèlius motyvuoja politinè darbotvarkè, tad "Nusikaltimo ir Bausmès“

\footnotetext{
${ }^{1}$ Žr. Lind W. S., "The Changing Face of War: into the Fourth Generation”, Marine Coprs Gazette, 1989, Spalis, pp. 22-26, ir Arquilla J. et al, "Networks, Netwar, and Information-Age Terrorism", in Howard R. D. \& Sawyer R. S. (red.), Terrorism and Counterterrorism: Understanding the New Security Environment, Guilford: McGraw-Hill/Dushkin, 2002, pp. 86-108.

${ }^{2}$ Carroll J., ,Is America actually at war?“, International Herald Tribune, 2006 m. sausio $30 \mathrm{~d}$.

${ }^{3}$ Plačiau žr.: Record J., Bounding the Global War on Terrorism, Carlyle: US Army War College Strategic Studies Institute, 2003, p. 2-6.

${ }^{4}$ Klausewitz K., On War, versta ir redaguota Michael Howard ir Peter Paret, Princeton: Princeton University Press, 1976, p. 75

${ }^{5}$ Ten pat, p. 605.

${ }^{6}$ Metz S., Millen R., Insurgency and Counterinsurgency in the $21{ }^{\text {st }}$ Century: Reconceptualizing Threat and Response, Carlyle: US Army War College Strategic Studies Institute, 2004, p. 2.
} 
diskursas, kuri daugelis bando taikyti terorizmo (o iš esmès vèlgi sukilimo ir kontrsukilimo) problematikos kontekste, yra neadekvatus ir niekur nevedantis strategine prasme.

\subsection{Sukilimo apibréžimas ir tipai}

Šioje vietoje galima pabandyti išsamiau apibūdinti sukilimą ir kontrsukilimą - šio konflikto esmę, pobūdį ir netgi tam tikrus raidos bruožus, atsižvelgiant ị tai, jog generalizacijos karo studijos yra šiek tiek pavojingos. Sukilimas yra apibūdinamas kaip legitimumo krizè, kurioje metamas iššūkis vienam ar keliems valstybės valdymo aspektams - nuo pačios valstybės egzistavimo legitimumo ar jos politinès ir socialinės santvarkos legitimumo iki konkrečios vyriausybės ar jos vykdomos politikos legitimumo ${ }^{7}$. Priklausomai nuo krizès pobūdžio ir sukilimo tikslų, nevyriausybines grupuotes, kurios susiorganizuoja ir imasi smurto tokioje krizèje, Bardas O'Neillas skirsto i keletą tipų:

- anarchistines, kurios atmeta bet kokį valdymą ir valdžią;

- egalitarines, kurios siekia radikaliais metodais pakeisti egzistuojančią socialinę sanklodą politinejje bendruomenèje;

- tradicines, kurios siekia atstatyti kažkada egzistavusią politinę santvarką, grindžiamą tradicinėmis vertybėmis; čia kalbama ir apie reakcinestradicines grupuotes, kurios siekia atstatyti senovinę politinę sistemą, idealizuojamą kaip „aukso amžius“;

- apokaliptines-utopines, daugiausiai religinius kultus;

- pliuralistines, siekiančias politinès sistemos, grindžiamos demokratinėmis vertybèmis;

- secesionistines, siekiančias atsiskyrimo nuo kokios nors politinės bendruomenès (valstybès);

- reformistines, kurios siekia pakeisti vyriausybės politiką;

- prezervacionistines, kurios siekia užkirsti kelią politikos pokyčiams;

- komercines, kurios paprasčiausiai siekia materialinio praturtèjimo politinès valdžios ir galios uzurpavimo būdü.

\subsection{Strateginiai sukilimo tikslai ir logika: auditorijos svarba}

Kad ir kokio pobūdžio sukilimas vyktu, jo strateginis tikslas yra formuoti visuomenès nuomonę ir požiūrị ị tą legitimumo aspektą, kuriam yra metamas iššūkis. Smurtas yra pasitelkiamas kaip įtikinèjimo priemonè, kuria siekiama diskredituoti valstybę, politinę santvarką, vyriausybę ar jos

${ }^{7}$ Plačiau žr.: O`Neill B., Insurgency and Terrorism: From Revolution to Apocalypse, Washington: Potomac Books, 2005, p. 15.

${ }^{8}$ Ten pat, p. $19-29$. 
vykdomą politiką, pritraukti pasekejjus ir juos mobilizuoti, įbauginti sukilimo priešininkus ir izoliuoti juos nuo valstybès valdžios. Metzas ir Millenas tai vadina "ginkluota propoganda", kuri, be visa ko, ir prisideda prie politinès rẻmejjų mobilizacijos". Smurto kampanija įtvirtina sukilèliu grupuotès „prekès ženklo" atpažįstamumą ir atkreipia visuomenès dèmesį i jos darbotvarkę. Kalbant strateginiais terminais, tokiam konfliktui galima lengvai pritaikyti konceptą, sukurtą ginkluotos galios tarpvalstybiniuose santykiuose panaudojimui paaiškinti. Șį konceptą, vadinamą ginkluotu įtikinèjimu (angl. armed suasion), pirmasis nuosekliai apibūdino Thomas Schellingas savo garsiojoje knygoje "Ginklai ir įtaka" (Arms and Influence, 1967 m.). Jo esmè yra ta, kad karinès galios demonstravimas, naudojimas ar grasinimas ją panaudoti yra pasitelkiami siekiant formuoti priešininku (ir sajungininkų) supratimą apie situacija, jos vertinimą ir sprendimus dẻl tolesnių veiksmų.

Šia strategine logika ir mechanizmu remiasi ir sukilèliu grupuotès. Anot Davido Galulos, prancūzu autoriaus, kuris dalyvavo kovoje su sukilèliais Alžyre, kiekviename sukilime svarbiausia yra ji stebinti auditorija, kurios nuomone ir palaikymas nulems konflikto baigti $i^{10}$. Pasak šio autoriaus, bet kokią auditoriją galima suskirstyti į nedidelę grupę, aktyviai palaikančią sukilèlius (kurią reikia išplèsti, nes nuo jos priklauso sukilèlių išgyvenimas, žvalgybinès informacijos ir logistikos prieinamumas ir pan.), tokią pat nedidelę grupę, palaikančią valstybès valdžią (kurią reikia įbauginti), ir pasyvią daugumą ${ }^{11}$. Būtent dèl šios pasyviosios daugumos situacijos suvokimo ir vyksta pagrindinis susirėmimas tarp sukilèlių ir kontrsukilèlių. Jau banalia tapusi frazè apie kovą dèl „,̌irdžių ir protu“", paplitusi po JAV invazijos 2003 m. į Iraką, yra kilusi iš šios konflikto apibūdinimo. Ne veltui Maxas G. Manwaringas akcentuoja, jog tokio karo „pagrindinis aspektas yra žodžių, vaizdinių ir idëjų naudojimas “12.

\subsection{Iššūkiai kontrsukilèliui}

Sukilimo sėkmė priklauso nuo daugybės veiksnių: geografiniu sąlygu, sukilèlių organizacijos, patirties, aktyviai remiančių visuomenès narių valios ir resursu, išorinės paramos ir saugaus prieglobsčio egzistavimo ir pan. Juos išvardyti ir išanalizuoti reikètų atskiro straipsnio, todèl čia galima apsiriboti dviem svarbiais aspektais. Pirmasis yra sukilèliu siekių patrauklumas visuomenei: jei šie siekiai yra suformuluoti taip, kad jie betarpiškai siejasi su visuomenëje egzistuojančiomis problemomis ir susikaupusiomis nuoskaudomis valstybés, politinès santvarkos ar vyriausybės atžvilgiu, sukilimas turi daug daugiau sèkmės galimybių. Pasak Galulos, „geriausias siekis yra toks, kuris pritraukia

${ }^{9}$ Plačiau žr.: Metz S., Millen R., (note 6) p. 4.

${ }^{10}$ Plačiau žr.: Galula D., Counter-Insurgency Warfare: Theory and Practice, London: Pall Mall Press, 1964, p. 8.

${ }^{11}$ Ten pat, p. $75-76$.

${ }^{12}$ Manwaring M. G., Shadows of Things Past and Images of the Future: Lessons for the Insurgencies in Our

Midst, Carlyle: US Army War College Strategic Studies Institute, 2004, p. 2. 
didžiausią kiekį rẻmëjų ir atstumia mažiausią skaičių oponentų “13. Būtent dèl šios priežasties kontrsukilèliai pagrindiniu savo taikiniu laiko sukilèliu siekius, kuriuos reikia arba diskredituoti, arba paprasčiausiai „pavogti“, t. y. pademonstruoti, jog šalies valdžia daro viską, kad tos visuomenès problemos ir nuoskaudos, kurios „maitina“ sukilima, yra rimtas valdžios rūpestis ir yra efektyviai sprendžiamos. Kitas svarbus aspektas yra paties kontrsukilèlio (t. y. valstybės valdžios) patirtis ir kompetencija malšinant sukilimus, jo lyderių pasiryžimas ir politinè valia, gaunama išorinè moralinè, politinè, finansinè ir karinè parama ${ }^{14}$. Kiekvienas karas, anot von Klausewitzo, yra dvikova ${ }^{15}$. Joje vienos pusės veiksmai sukelia kitos pusės atsaką ir veiksmus, oponentai reaguoja ir adaptuojasi prie besikeičiančių aplinkybių. Kontrsukilèlio įvaizdis visuomenès akyse bei jo veiksmai didžia dalimi lemia sukilimo baigti, todèl sukilèliai, naudodami smurtą, stengiasi pademonstruoti jo silpnumą, nekompetenciją, izoliuotumą bei savo potenciją ir, svarbiausia, išprovokuoti valstybės valdžios neadekvatu ir neproporcingą atsaką. Toks atsakas formuoja neigiamą visuomenės nuomonę ir didina sukilëlius remiančių visuomenès narių gretas ${ }^{16}$.

Kontrsukilèlio padètis dažnai yra nepavydètina. Visu pirma sukilimo požymiai dažnai pasireiškia tik tada, kuomet didžioji dalis politinės dimensijos jau yra suformuota sukilèliams teigiama linkme. Valstybès valdžia dažnai neranda sukilimo prielaidu ir formavimosi ankstyvojoje stadijoje, kuomet vyksta sukilèlių pogrindinis organizavimasis, todèl jai tenka reaguoti į smurtą, kurio prievartinèmis valstybei prieinamomis priemonemis jau praktiškai neįmanoma nuslopinti ir neutralizuoti, nebent represuojant dalį visuomenės. Tai vadinama laipsnišku perëjimu į karą; ir valstybės valdžia dažnai nesuvokia, kada reikia pradèti taikyti karui būdingas ypatingąsias priemones, arba, jei tai ir suvokia laiku, susiduria su visuomenès neigiamu nusistatymu prieš tokias priemones $^{17}$. Maža to, tarp sukilèlio ir kontrsukilèlio visada egzistuoja atsakomybės asimetrija. Valstybẻs valdžia turi pareigą užtikrinti tvarką ir saugumą visoje savo teritorijoje -ji turi apsaugoti šalies ekonominę, finansinę ir administracinę infrastruktūrą, ginti piliečius ir jų turtą. Sukilèliai, neturẻdami tokių pareigu, sumaniai išnaudoja šią asimetriją, priversdami valdžią "persitempti“ stengiantis išsaugoti valstybès teritorijos kontrolę. Ne veltui sukilimas yra dažnai vadinamas "blusų karu“, kuriame „blusos“" (sukilèliai) tiesiog nualina „šunįi” (valstybės valdžią) nuolatinemis atakomis ir išpuoliais, į kuriuos neįmanoma visada ir visur atsakyti arba jiems užkirsti kelią ${ }^{18}$. Dauguma autoriu sutaria, kad kontrsukilëlio administraciniai pajègumai, gebejjimas išlaikyti šalies ir jos piliečiu kontrolę, nepalikti valdymo vakuumo, kuriame galètų susikurti alternatyvios sukilèlių valdymo struktūros, yra labai svarbūs kontrsukilèlio atsako aspektai. Ne mažiau svarbi yra visų valstybinių instituciju - kariuomenès,

\footnotetext{
${ }^{13}$ Galula D., (note 10) p. 19.

${ }^{14}$ Ten pat, p. 26-27.

${ }^{15}$ Klausewitz K., (note 4) p. 75.

${ }^{16}$ Plačiau žr.: O'Neill B., (note 7) p. 104-106.

${ }^{17}$ Plačiau žr.: Galula D., (note 10$)$ p. 9.

${ }^{18}$ Pirmasis analogija panaudojo Robertas Taberis, žr. Taber R., The War of the Flea: A study of guerilla warfare theory and practice, L. Stuart, 1965.
} 
žvalgybos tarnybu, policijos, finansinės kontrolės instituciju, migracijos tarnybu, diplomatinių žinybų, ekonomikos ir netgi švietimo instituciju - koordinacija kontrsukilimo kampanijos metu. Gal tik penktadalis visų pastangų malšinant konfliktą yra sukoncentruotos karinëje ir policinëje dimensijose ${ }^{19}$. Didžioji jo dalis vyksta politinëje, socialinëje, ideologinëje ir propogandinëje plotmėse. Kiekvienas karas yra politikos tęsinys, tačiau sukilimas ir kontrsukilimas yra absoliučiai politinis karas, dominuojamas sąveiku politineje dimensijoje ${ }^{20}$. Todèl dauguma autorių sutaria, kad nèra grynai karinių priešnuodžių sukilimui, ką aiškiai suponuoja ir strateginis kontrsukilëliu tikslas - perimti arba diskredituoti sukilèliu siekius ir atskirti sukilèlius nuo visuomenès, kuria jie naudojasi savo operacijoms palaikyti. Tai yra karas tarp dvieju politiniu, socialiniu, ekonominiu, administracinių, karinių, žvalgybinių ir informacinių tinklų, besivaržančių dèl visuomenès palankumo. Būtent konkuruojančių tinklų samprata sudaro jau minètu „,ketvirtos kartos karo" (4GW) ir "tinklakario" koncepciju pagrindą. Informacijos revoliucijos amžiuje tokių tinklų suformavimą ir funkcionavimą itin palengvina internetas ir mobiliosios komunikacijos. Pasak Arquillos, Ronfeldto ir Zaninio, „,tinklakaris apibūdina konfliktą visuomenès lygyje, kuriame jo dalyviai naudoja tinklo konfigūracijos organizaciją ir su ja susijusias doktrinas, strategijas ir technologijas, igalintus informacijos amžiaus ${ }^{\prime 21}$.

Bet kokiu atveju sukilimas ir kontrsukilimas yra ilgas, metų metus ar net dešimtmečius besitęsiantis karas, kuriame abi pusės tiesiog stengiasi kuo ilgiau išlikti ir išsilaikyti. Ne veltui Mao savo teoriją vadina „ištęstu liaudies karu“. Anot Metzo ir Milleno, „dažnai sukilimai tęsiasi taip ilgai, jog gimsta ištisos kartos, nežinančios nieko kito, tik konfliktą “22. Maža to, sukilëliai naudoja laiką kaip ginklą, nes, pasak Denniso Drew'o, „kiekviena diena, kol sukilèliu judèjimas tęsia savo egzistavimą [...], diskredituoja vyriausybę ir jos gebèjimą efektyviai valdyti šalį ir kontroliuoti savo likimą “23. Turint omeny, jog, norint laimèti, sukilèliams pakanka paprasčiausiai išlikti ir tai pademonstruoti, laikas dažniausiai yra jų sajungininkas.

Šis pakankamai detalus ekskursas į sukilimo ir kontrsukilimo teoriją suteikia pagrindą pamėginti nagrinèti jos taikymą globaliu lygiu - konfliktui tarp JAV ir Al Qaedos organizacijos analizuoti. Tiesa, apibūdinant JAV strategiją šios teorijos rẻmuose, bus pasitelkiama papildomų teorinių minčiu ir modeliu, kuriems neliko vietos aprašant pagrindinius teorinius sukilimo ir kontrsukilimo postulatus. Tačiau paralelëms tarp "globalinio karo su terorizmu" ir sukilimo / kontrsukilimo išvesti teorinių idëjų turètu pakakti. Kita šio straipsnio dalis ir yra skirta tokiu paraleliu sudarymui.

\footnotetext{
${ }^{19}$ Ten pat, p. 89.

${ }^{20}$ Plačiau žr.: Manwaring M. G., Shadows of Things Past and Images of the Future: Lessons for the Insurgencies in Our Midst, Carlyle: US Army War College Strategic Studies Institute, 2004, p. 2.

${ }^{21}$ Arquilla J., Ronfeldt D., Zanini M., „Networks, Netwar, and Information-Age Terrorism“ in Howard R. D., Sawyer R. L., eds., Terrorism and Counterterrorism: Understanding the New Security Environment. Readings and Interpretations, Guilford: McGraw Hill / Dushkin, 2004, p. 90.

${ }^{22}$ Metz S., Millen R., (note 6) p. 5.

${ }^{23}$ Drew D. M., Insurgency and Counterinsurgency: American Miliary Dilemmas and Doctrinal Proposals, Air University Press, 1988, p. 6
} 


\section{Al Qaedos iššūkis ir JAV atsakas: konflikto logika ir "gramatika“ pagal sukilimo ir kontrsukilimo teorija}

Šiame skyriuje bus bandoma atsakyti į pagrindinį straipsnio klausimą: ar sukilimo ir kontrsukilimo teorija gali paaiškinti konfliktą, kurị jau esame ipratę vadinti „globaliniu karu su terorizmu“? Kaip remiantis šia teorija galima interpretuoti Al Qaedos ir JAV strategijas šiame konflikte? Ar konflikto pobūdis atitinka pagrindinius sukilimo ir kontrsukilimo teorijos teiginius? Kiek globali šio konflikto apimtis apriboja teorijos pritaikymą? O galbūt reikètų ieškoti ir formuluoti visiškai naują karo teoriją, galinčią tiksliau ir išsamiau apibūdinti "globalinį karą su terorizmu“?

\subsection{Al Qaeda ir jos tikslai: supra-nacionalinè darbotvarkè}

Pradèti reikètu nuo Al Qaedos grupuotès ir jos tikslų apibūdinimo. Jau pats faktas, jog Al Qaeda nèra valstybinis tarptautiniu santykių veikẻjas, paskatina ieškoti sąlyčio taškų su teorijomis, kurios atsižvelgia į šiuos veikejjus. Karo studijose vienintele tokia yra būtent sukilimo ir kontrsukilimo teorija. Tačiau čia iškyla pirmasis sunkumas: sukilimo ir kontrsukilimo teorija nagrinëja ginkluotą konfliktą valstybės viduje. Al Qaedos tikslai vargu ar suponuoja apsiribojimą konkrečios valstybès sienomis. Jos lyderio Osamos bin Ladeno pareiškimai bei juos lydintys veiksmai atskleidžia daug globalesnes ambicijas. Iš esmès Al Qaeda siekia suvienyti islamo bendruomenę (umma), nuo Šiaurès Afrikos ir Artimujų Rytų iki Centrinès, Pietų ir Pietryčių Azijos bendrą kalifatą, valdomą pagal islamo ịstatymus ${ }^{24}$. Nèra jokios abejonès, kad tai politinis tikslas, nors ir įkvèptas religijos bei jos istorinès praeities. Pasak Jasono Burke'o, „šis teologinis bendrumo, arba vienybės, principas [...] yra fundamentalus ir itin politinis konceptas. Daugelis musulmonu, įskaitant ir bin Ladena, yra įsitikinę, kad šiam principui reikia suteikti politinę išraišką sunaikinant musulmonu pasidalijimą, nacionalinį ar kokị kitą, ir suvienijant umma“25. Bet kokie oponentų bandymai traktuoti ginkluotą smurtą tiesiog kaip aklą ir fanatišką naikinimą vardan kažkokių utopiniu, ne šio pasaulio, religiniu tikslų visiškai ignoruotu Al Qaedos politinę darbotvarkę. Naudojant O'Neillo klasifikaciją, Al Qaeda yra reakcinè-tradicinè sukilèlių grupuotė, siekianti atkurti prarastą islamo reputaciją ir įtaką pasaulyje, kuri egzistavo ankstyvaisiais viduramžiais. Jos politinè darbotvarkė veda ir prie strateginių organizacijos tikslu, kurie vèlgi išreikšti labai aiškiai: likviduoti Vakaru politinę, ekonominę, kultūrinę ir karinę įtaką islamo pasaulyje, kuri esą veda prie musulmonu bendruomenès ir kuri suinteresuota islamo susiskaldymu ir silpnumu; nuversti korumpuotus repres-

\footnotetext{
${ }^{24}$ Plačiau žr.: Fowler M. C., Amateur Soldiers, Global Wars: Insurgency and Modern Conflict, London: Praeger Security International, 2005, p. 2.

${ }^{25}$ Burke J., Al Qaeda: the True Story of Radical Islam, London: I. B. Tauris, 2004, p. 27.
} 
inius režimus musulmoniškose šalyse, kurie esą vykdo vien tik Vakaru valią ir neleidžia islamo bendruomenei atgimti ir susivienyti bendroje valstybeje ${ }^{26}$. Kad ir kokie idealistiniai ir ambicingi šie tikslai bebūtu, karas, kaip priemonė jiems pasiekti, gali būti vienas iš racionalių politikos instrumentų. Tačiau karas su kuo?

Sukilimo ir kontrsukilimo teorijoje oponentas yra šalies vyriausybè. Galima sakyti, kad Al Qaedos globaliniai tikslai veda prie konflikto su daugeliu oponuojančių vyriausybių ir politinių sistemu, kurių legitimumą grupuoté kvestionuoja - ar tai būtų Saudo Arabija, ar Jordanija, ar Pakistanas. Netgi Al Qaedos organizaciniai principai verstu manyti, kad tiesiog susiduriame su grupuote, kuri bando daryti įtaką procesams valstybiniu lygiu: su Al Qaeda ryšius palaiko ir jos paramą gauna daugelis valstybiu viduje iki šiol veikusiu musulmonu sukilèliu grupuočių ${ }^{27}$. Bet du aspektai rodo, kad sukilimo mastai yra daug didesni ir kad jis paliečia ne tik paskiras vyriausybes ar politines sistemas tam tikrose valstybèse. Tai - pasirinktas pagrindinis priešininkas, t. y. Jungtinès Amerikos Valstijos, ir sukilimo pagrindą sudaranti nuoskauda, aplink kurią formuojama Al Qaedos ideologija ir strategija, t. y. menama viso pasaulio musulmonų priespauda ir pažeminimas, kuriuos esą sukelia dabartinė pasaulio tvarka ir kurios pagrindinis ,"agentas" yra JAV ${ }^{28}$. Pats bin Ladenas savo 1998 m. paskelbtoje „,karo deklaracijoje“ daro tokį pareiškimą: „Ne paslaptis, [...] kad Islamo žmonės patiria judejjų ir krikščionių aljanso ir jų rèmëjų priespaudą, priešiškumą ir neteisingumą [...]. Amerikos imperinè argonacija, pridengiama nemoraliu Jungtinių Tautu, neleidžia nuskriaustiesiems ginkluotis ir sukilti" ${ }^{\prime 29}$. Būtent čia glūdi pagrindinès Al Qaedos inspiruoto ir vedamo sukilimo, t. y. legitimumo krizès, šaknys. Tačiau tokiu atveju jau reikia kalbèti apie tai, kad legitimumo krizė, bent jau Al Qaedos ir jos rẻmëju akimis žiūrint, ištiko ne atskiras politines sistemas ar politinius režimus musulmoniškose valstybėse, o visą pasaulio tvarką, kurią palaiko globalinis hegemonas - Jungtinè Valstijos - su savo politine, ekonomine, karine ir kultūrine galia. Al Qaedos politinių tikslų pobūdis užprogramavo konfliktą su JAV, kuris, dèl JAV įtakos ir vietos tarptautinëje sistemoje, tapo globaliu konfliktu. Tačiau tarptautinè sistema ir valstybė, kaip du skirtingi analizės lygmenys ir skirtingos politinės konflikto aplinkos, gali taip lengvai nepasiduoti tos pačios - sukilimo ir kontrsukilimo - teorijos taikymui. Be to, vien tai, kad "globalinio karo su terorizmu“ šaknys iš esmès glūdi politinio legitimumo krizeje ir kad konfliktas vyksta tarp valstybinio ir nevalstybinio veikèju, tik ne valstybės, o tarptautinès sistemos lygiu, dar nereiškia, kad ši karą galima klasifikuoti kaip sukilimą ir kontrsukilimą. Daug svarbesnè yra strateginè konflikto logika, kuria vadovaujasi abi pusès.

\footnotetext{
${ }^{26}$ Plačiau žr.: Sageman M., Understanding Terror Networks, Philadelphia: University of Pennsylvania Press, 2004, p. 18-19.

${ }^{27}$ Ten pat.

${ }^{28}$ Plačiau žr.: Fishel K. L., „, Challenging the Hegemon: Al Qaeda’s Elevation of Asymmetric Insurgent Warfare Onto the Global Arena", Low Intensity Conflict \& Law Enforcement vol 11, No. 2/3, 2002, p. 285-298.

${ }^{29}$ Plačiau žr.: Lawrence B., Messages to the World: the Statements of Osama bin Laden, London: Verso, 2005 , p. 25 .
} 


\subsection{Strateginè logika: vaizdinių ir idèjų karas}

Pats svarbiausias "globalinio karo su terorizmu“, kaip sukilimo ir kontrsukilimo, testas glūdi ten, kokị vaidmenį konflikte vaidina ir kaip sąveikauja karinè galia, ideologija ir propoganda. Kaip jau buvo minèta pirmojoje dalyje, sukilime ir kontrsukilime smurtas yra naudojamas kaip įtikinejjimo priemonė, sustiprinanti ir komunikuojanti ideologinę „žinią“" bei formuojanti konfliktuojančiu pusiu įvaizdị stebinčios auditorijos akyse.

Al Qaedos kampanija prieš JAV hegemoniją prasidejjo kur kas anksčiau nei teroro aktai 2001-ujjų rugsejjo $11 \mathrm{~d}$. Dar iki to buvo įvykdyti išpuoliai prieš JAV ambasadas Kenijoje ir Tanzanijoje bei prieš JAV karinį laivą USS Cole Adeno uoste Jemene. Tačiau būtent rugsëjo 11-osios atakos Niujorke ir Vašingtone, kuriems dramatizmo prasme sunku rasti lygiu karinejje ir politinëje pasaulio istorijoje ir kuriu pasekmės buvo tiesiogiai transliuojamos naujienų kanalais visam pasauliui, įtvirtino Al Qaedą kaip lygiavertị hegemono priešininką. Kaip rašo vienas žymiausių šiuolaikinių strategijos ekspertų Colinas Gray'us, Al Qaeda ,igijo istorinio nugalètojo aureolę. Islamo kariai pažemino didžiają galybę - JAV. Šis ịsitikinimas vaidina stiprų vaidmenį kaip pasitikëjimo savimi ir prestižo šaltinis ${ }^{\prime \prime 30}$. Galima tvirtai teigti, jog smurtas buvo panaudotas ne šiaip dèl fizinio naikinimo, kaip strateginio tikslo. Al Qaedos strategai akivaizdžiai siekè dviejų pagrindinių tikslų:

1. İtvirtinti grupuotės „prekės ženklo“ žinomumą islamo pasaulyje ir už jo ribur. Drąsus ir efektyvus išpuolis neabejotinai padejo pritraukti nauju pasekejju ${ }^{31}$. Būtent nuo tada grupuotè pradèjo ịgyvendinti savo siekị tapti pagrindiniu pasaulio musulmonu nuoskaudu laidininku, kuris mobilizuoja ir nukreipia susikaupusią energiją reikiama linkme. Didžiaja dalimi pagrindinė atakų auditorija buvo būtent pasaulinė musulmonų bendruomenė, kuriai buvo įtikinamai pademonstruotas "didžiojo blogio“ (JAV) pažeidžiamumas.

2.Išprovokuoti neproporcingą JAV atsaką, kuris turẻjo dar labiau pastūmėti abejojančius Al Qaedos tikslais ir siekiais i šios grupuotės pusę ${ }^{32}$. Sukilimo ir kontrsukilimo teorijoje pasyvioji dauguma, kurios palaikymas yra būtinas sukilèlio (arba kontrsukilèlio) tikslams pasiekti, yra pagrindinis konflikto objektas.

Lygiai taip pat kaip ir bet kuriame sukilime, smurtas čia taip pat naudojamas trečiosioms šalims pasitraukti iš konflikto, nustoti remti oponentus. Tuomet smurto auditorija tampa tų šaliu visuomenès. Ši logika slypejo už teroro aktų Madride 2003 m., įvykdytų prieš pat Ispanijos parlamento rinkimus ir sugebëjusiu pakreipti visuomenès nuomonę taip, jog rinkimuose nugalëjo partija, siekusi išvesti Ispanijos karinį kontingentą iš Irako ${ }^{33}$. Sutapimas ar ne,

\footnotetext{
${ }^{30}$ Gray C. S., Another Bloody Century: Future Warfare, London: Weidenfeld \& Nicolson, 2005, p. $237-$ 238.

${ }^{31}$ Plačiau žr.: Fowler M. C., (note 24) p. 6.

${ }^{32}$ Ten pat.

${ }^{33}$ Geriausiai tai iliustruoja Osamos bin Ladeno pareiškimas „Europos žmonėms“, plačiau žr.: Lawrence B., (note 29) p. 233-236.
} 
bet teroro aktai Londono metro $2005 \mathrm{~m}$. liepą ívykdyti kitą dieną po to, kai miestas buvo paskelbtas $2012 \mathrm{~m}$. vasaros olimpinių žaidynių vieta: planuotai ar ne, britams ir visai tarptautinei bendruomenei pasiųsta žinia, kad šalis nebus saugi tol, kol Britanija vaidina tokị svarbų vaidmenį JAV vadovaujamoje "globalinio karo su terorizmu“ koalicijoje.

Pačios JAV, po $2001 \mathrm{~m}$. rugsèjo 11-osios paskelbusios "globalinio karo su terorizmu" pradžią, sugebejo išvengti neproporcingo atsako spąstu, bent jau kurį laiką. Kampanija Afganistane buvo ribota, apsiëjusi be ypatingu karinès jëgos panaudojimo ekscesu. Bet jau nuo tada dauguma JAV ir ju sajungininku veiksmų ėmé tiekti propogandinę amunciją Al Qaedos politinei ir ideologinei mašinai. Nuo Prezidento George'o W. Busho kalboje praslydusio atsitiktinio karo su terorizmu prilyginimo kryžiaus žygiams ir talibu kovotoju įkalinimo Guantanamo bazèje iki Irako okupacijos ir JAV kariụ elgesio Abu Ghraibo kalëjimo kalinių atžvilgiu bei įtariamų teroristų perdavimo trečiosioms šalims, kur jie buvo kankinami, - viskas pasitelkiama kaip įrodymas to, jog JAV ir ju sajungininkai siekia pratęsti musulmonu pažeminimą ir jungą. Pavyzdžiui, viename bin Ladeno pareiškimu, komentuojančių invaziją ị Iraką, sakoma: „Amerika kariauja dèl religinių ir ekonominiu paskatu, kurios taip pat gelbsti žydu valstybei nukrepiant dėmesi nuo Jeruzalès okupacijos ir musulmonu žudymo ten. Tam nèra geresnio įrodymo nei jų noras sunaikinti Iraką [...] ir ju pastangos suskaldyti visas valstybes regione [...] i popierines mažas valstybes, kuriu silpnumas ir vienybės stoka garantuoja Izraelio išlikimą ir kryžiuočiu vykdomą brutalią [Arabijos] pusiasalio okupaciją “34. Netgi JAV nenoras spausti Izraeli pastarojo karinés intervencijos Libane $2006 \mathrm{~m}$. rudenį metu pasitelktas kaip pasaulinio sąmokslo prieš musulmonus patvirtinimas. Tokioms musulmonų nuomonės formavimo, naudojant prieš JAV, apskritai Vakarus ir prieš režimus musulmoniškose valstybėse nukreiptą terorą ir propogandą, pastangoms itin gelbsti žiniasklaidos, ypač interneto ir palydovinès televizijos, sklaida. Vienas pagrindinių Al Qaedos ideologų ir strategų egiptietis Aymanas al-Zawahiris tam skyrė ypatingą dèmesį savo traktate "Riteriai po pranašo vèliava“"35. Šiuos būdus Al Qaeda išnaudoja itin aktyviai ir meistriškai, nors ir pačios organizacijos ekscesai (pvz., bombos sprogimas viešbutyje Amane per vestuves arba kameromis užfiksuojami įkaitų Irake nukirsdinimai) galëjo turèti neigiamą poveikị pasaulio musulmonų nuomonei.

Al Qaeda pamažu, spaudžiama JAV karinès kampanijos, ėmė transformuotis i judèjimą, kurio pasekëjai, lyderiu įkvejpti, patys imasi iniciatyvos ir vykdo smurtinius aktus. Al Qaeda tik suteikia krypti, kai kada tam tikrus finansus ir apmokymą, galbūt parenka reikiamą laiką, bet svarbiausia - legitimizuoja „pasipriešinimą“" Vakaru priespaudai. Pasak Burke, dabar Al Qaedos pavadinimą reikia versti ne kaip „bazė", bet kaip „principas“ (maxim) ${ }^{36}$. Nuo musulmonu paaugliu Jungtineje Karalystejje iki turtingu Persijos įlankos verslininku, nuo Egipto studentų iki Pakistano prekeiviu ir Indonezijos valstiečių Al Qaedos

\footnotetext{
${ }^{34}$ Ten pat, p. 60.

${ }^{35}$ Plačiau žr.: Sageman M., (note 26) p. 20.

${ }^{36}$ Burke J., (note 25) p. 290.
} 
ideologinis judėjimas yra tapęs tokiu pat globaliniu reiškiniu, kaip ir iki tol-jos gebëjimas projektuoti karinę galią. Bet kokie teroro aktai - Londone, Balyje, Stambule, Amane ar Er Rijade - jau yra tik tebesitęsiančio ir stiprëjančio sukilimo simptomai. Tą puikiai supranta dauguma Vakarų strategu, raginančiu grumtis su sukilimo šaknimis, o ne išraiškomis. Tad savo strategine logika "globalinis karas su terorizmu“ yra iš tikrujų sukilimas ir kontrsukilimas - karas, kuriame įvaizdžiai, idëjos ir perspecijos sudaro svarbiausią dimensiją.

\subsection{Kontrsukilèlio atsakas: globalinès dimensijos specifika}

Tiems, kas priima „Amerikos imperijos“ (Pax Americana) tezę, Al Qaedos iššūkis nèra naujas ir netgi originalus. Daugelis Vakaru pasaulio imperiju, pavyzdžiui, Romos, Britanijos, žlugo spaudžiamos sukilëliu, kvestionuojančių jų legitimumą. Tačiau sukilimo ir kontrsukilimo teorijos pritaikymas Al Qaedos ir JAV konfliktui reikalauja, kad prilygintumėme JAV galią tarptautiniuose santykiuose vyriausybiu galiai ir teisėms valstybiu viduje. Vargu ar tarp ju įmanoma dèti lygybės ženklą, o pasekmès gan svarbios turint omenyje šio straipsnio tikslą: vyriausybė, kaip kontrsukilèlis, gali sau leisti vienokias priemones ir strategijas kovoje su sukilëliais; valstybė, veikianti anarchiškoje tarptautineje sistemoje, kurioje egzistuoja kitos suverenios valstybės, turi veikti kitaip. Vargu ar "globaliniame kare su terorizmu“ JAV gali leisti sau netrukdomą ginkluotos jėgos panaudojimą bet kokioje valstybëje, kaip kad šalies vyriausybė gali tai daryti valstybės viduje. Valstybiu suverenitetas, nors ir susilpnintas globalizacijos ir regionalizacijos procesu, vis dar tebera tarptautinès sistemos pagrindas. Tad ir JAV galios naudojimas susiduria su iš to kylančiais apribojimais bei imperatyvais, kaip kad būtinybė užsitikrinti bent kiek ženklesnę tarptautinès bendruomenės politinę paramą kariniams veiksmams bei sudaryti susitarimus dèl karinių pajègu perdislokavimo per kitu šalių teritorijas. Tuo tarpu klasikiniame sukilime vyriausybė nėra varžoma kitu valstybių suvereniteto, nebent sukilëliai randa prieglobsti trečiosiose šalyse. Tam tikrą šios problemos sprendimą gali suteikti tinklakario konceptas, trumpai pristatytas pirmojoje darbo dalyje ir kurio viena pagrindinių minčiu yra ta, kad su organizacinis tinklais efektyviai galima supriešinti tik kitą tinklą. Valstybès viduje toks kontrsukilèlio tinklas susiformuoja aktyvios ịvairiu vyriausybės agentūrų ir struktūrų bei jų rẻmëjų sąveikos dẻka, o štai tarptautinëje sistemoje JAV remiasi globaliniu draugišku valstybių ir sajungininkų tinklu, kuris padeda, bent jau iš dalies, iqveikti valstybiu suvereniteto barjerus globalinëje kontrsukilimo kampanijoje. Tokiame tinkle lengvai keičiamasi informacija, suteikiami reikiami leidimai ir parama žvalgybinei ir karinei veiklai, imamasi bendru veiksmu, pavyzdžiui, finansiniams srautams stebėti ir pan. ${ }^{37}$ Tačiau norint visiškai igyvendinti tinklakario (arba giminiško $4 \mathrm{GW}$ ) konceptą iš

\footnotetext{
${ }^{37}$ Daugianacionalinio tinklo kūrimą ,kare su terorizmu“, kaip priešpriešą globaliam Al Qaedos tinklui, siūlo Johnas Sullivanas ir Robertas Bunkeris, plačiau žr.: Sullivan J. P., Bunker R. J., „Multilateral Counter-Insurgency Networks“, Low Intensity Conflict \& Law Enforcement vol. 11, No. 2/3, 2002, p. 353-368.
} 
kontrsukilèlio pusès, JAV turi integruoti į savo tinklą ne tik valstybes, bet ir nevyriausybines bei tarptautines organizacijas, žiniasklaidą, privatų sektorių, internetines bendruomenes, religines musulmonu grupes ar net karo vadus lokalinių konfliktų zonose. Priešingu atveju sukilèliu, t. y. Al Qaedos tinklas, veikiantis nepaisydamas valstybiu sienu ir suvereniu galiu ir sudarytas iš nevalstybinių komponentu, nesutiks pasipriešinimo ten, kur jis yra svarbiausias toje neaiškiai apibrèžtoje ir nuolat besikeičiančioje erdvëje, kuri vadinama tarptautine bendruomene, ypač jos musulmoniškoje dalyje. Nesunku suvokti, jog tokios apimties tinklo kūrimas ir palaikymas yra milžiniškas uždavinys, o jo efektyvumas globaliu lygiu, suverenios valstybės vyriausybei šalies viduje stokojant prieinamu galios šaltinių ir instrumentu, išlieka abejotinas.

Galimos ir tolesnès paralelès tarp sukilimo valstybès viduje ir tarptautinès sistemos lygiu: visu pirma viena pagrindiniu "globalaus karo su terorizmu" problemų yra vadinamosios ,„žlugusios valstybès“, kurias teoriškai galima prilyginti kokios nors šalies provincijoms, nekontroliuojamoms centrinès valdžios ir naudojamoms sukilèlių savo kampanijai vykdyti. Valstybès instituciju atkūrimas tose provincijose yra vienas pagrindinių kontrsukilëlio uždavinių. Lygiai taip pat „žlugusių valstybių", potencialiai galinčiu virsti teroristų prieglobsčiu, atstatymas tampa vienu svarbiausių JAV ir jų sajungininku rūpesčiu, ką demonstruoja besitęsianti kampanija Afganistane. Antra, kaip ir sukilèliai valstybès viduje, taip ir Al Qaeda neturi tokiu įsipareigojimu ar apribojimu, kurie paprastai riboja vyriausybiu veiksmu laisvę. Šiuo atveju JAV, kad ir kaip besistengtu rasti „novatoriškų" sprendimų ir pasiteisinimu, galiausiai turi laikytis tarptautinės teisės normų. Tokia įsipareigojimų asimetrija yra būdinga būtent sukilimo ir kontrsukilimo dinamikai. Al Qaeda yra vienas iš nedaugelio tarptautinès sistemos veikëju, gebančiu projektuoti karinę galią bet kur pasaulyje (pakanka atkreipti dėmesį i įvykdytų ar sutrukdytų teroro aktu geografiją) ir atliekančių tai be jokių moralinių ar sisteminių apribojimų ${ }^{38}$. Maža to, globali kampanija vykdoma turint minimalius (lyginant, pavyzdžiui, su JAV kariniu biudžetu) resursus. Tai taip pat atitinka klasikinės sukilimo ir kontrsukilimo teorijos teiginį, jog sukilimas yra "pigus karas“, žvelgiant iš sukilèlio poziciju.

Toliau analizuojant klasikinę sukilimo ir kontrsukilimo teoriją, kontrsukilèliai (JAV ir jų sajungininkai) bando ieškoti ideologinių ir politiniu priešnuodžiu, kuriuos naudojant Al Qaedos tikslai būtų neutralizuoti, o pats judèjimas marginalizuotas ir izoliuotas nuo didžiosios musulmonų daugumos. Vienas iš tokios strategijos elementų buvo, bent jau iki fiasko Irake ir radikaliosios Hammas grupuotès tapimo valdančiaja partija Palestinos savivaldoje demokratinių rinkimu keliu, Artimujų Rytų demokratizacijos iniciatyva. Baltieji Rūmai ją pateikẻ kaip alternatyvą Al Qaedos siūlomai musulmonų pasaulio vizijai ir bande įteigti, kad būtent demokratizacija ir liberalizacija, o ne smurtas ir teokratinè diktatūra (daug kartu įvardyta kaip analogas fašizmui) yra tas kelias ir mechanizmas, kuriuo pasinaudodami musulmonai gali atgauti savo įtaką ir vaidmenị. JAV administracija netgi ėmėsi tam tikro spaudimo

${ }^{38}$ Plačiau žr.: Fowler M. C., (note 24) p. 6. 
draugiškiems režimams musulmonų pasaulyje (pvz., Egiptui, Saudo Arabijai), kad priverstu juos eiti reformu keliu. Anot $\mathrm{O}^{\prime}$ Neillo, būtent esminių reformu inicijavimas ir yra ta strategija, kuri izoliuoja ir nuslopina sukilimąa ${ }^{39}$. Tačiau panašu, kad JAV neturi nei reikiamų svertu suvereniose valstybėse, nei pakankamai politinès valios juos panaudoti, ypač kuomet mato trumpalaikę strateginę naudą palaikyti nedemokratiškus režimus bei pavoju, jog tie patys demokratiniai mechanizmai bus išnaudoti radikalų atëjimui į valdžią. Tokị raidos scenariju, pavyzdžiui, branduolini ginklą turinčiame Pakistane galima lengvai priskirti košmarams. Todèl nenuostabu, kad JAV pamažu praranda entuziazmą demokratizavimo strategijai, o jokios alternatyvos, kuria galima būtų perimti Al Qaedos ideologinę iniciatyvą, vis dar nerasta.

Bene įdomiausias konvergencijos tarp klasikinės sukilimo ir kontrsukilimo teorijos bei "globalaus karo su terorizmu“ pavyzdys yra pačiu JAV pripažinimas, jog būtent ši teorija dabar sudaro JAV strategijos pagrindą. 2006ujų strateginès peržiūros dokumentas cituoja teorijos klasikus ir akcentuoja karinès galios ribotumą šiame konflikte bei būtinybę derinti karinius veiksmus su politine, diplomatine, ekonomine, socialine, propogandine, žvalgybine ir juridine dimensijomis. Visiškai pagal teoriją, JAV strategai pripažino, jog tai bus ilgas karas: netgi pats dokumentas turi antraštę „Ilgas karas“. Karinè galia suvokiama tik kaip instrumentas, kuriuo pasiekiamas tam tikras sulaikymo bei saugumo jausmo efektas, kol konfliktas neišsispręs kovos dẻl „širdžiu ir protu“ dimensijoje, ko ir reikalauja sukilimo ir kontrsukilimo teorija ${ }^{40}$. Deja, nors karine prasme JAV tampa pakankamai kompetentingu kontrsukilèliu, pagrindinëje - idèjinès ir politinės kovos - plotmëje daroma labai mažai, o tuo tarpu bet kokios karinés ir politinés klaidos yra Al Qaedos ir jos šalininkų ir toliau panaudojamos JAV reputacijai musulmonų pasaulyje naikinti. Akivaizdžiai trūksta JAV įdirbio toje kontrsukilèlio tinklo dalyje, kurią sudaro nevalstybiniai veikèjai, galintys suteikti geresnę atramą musulmonu „širdžių ir protų" atkariavimo kampanijoje, nei kai kurie draugiški, bet itin musulmonų akyse susikompromitavę valstybiniai režimai.

Jungtinès Valstijos, kaip ir dauguma vyriausybių praeityje, susidūrusių su sukilimo tipo karais, praleido pro akis latentinę globalaus sukilimo prieš ju dominavimą fazę, kuomet vyko Al Qaedos politinis ir karinis organizavimasis. Aktyviu veiksmu stadijoje, besistengiant prislopinti sukilimo intensyvumą, yra kukliu pasiekimu (pavyzdžiui, nepraleidžiama progos pabrèžti, kad nuo $2001 \mathrm{~m}$. rugsëjo 11-osios išpuoliu Al Qaeda daugiau nesugebẻjo smogti Jungtinèms Valstijoms ju pačiu teritorijoje), bet padaryta ir daug strateginiu klaidų. Pripažinus, kad „globalinis karas su terorizmu“ yra ne kas kita, kaip globalinis sukilimas ir kontrsukilimas, galbūt dar daugiau klaidų bus išvengta, tačiau ilgame kare pergalè bus tokia pat nepastebima, kaip ir karo pradžia.

\footnotetext{
${ }^{39}$ Plačiau žr.: O`Neill B., (note 7) 8 skyrius.

${ }^{40}$ Plačiau žr.: Quadrennial Defense Review Report, Washington D.C.: U.S. Department of Defense, 2006, www.defenselink.mil/qdr/report/Report20060203.pdf , 2006-08-18.
} 


\section{Išvados}

Terminas „globalus karas su terorizmu“ yra jau tapęs šablonu, o terorizmo ekspertai žeria patarimus ir strategijas, kaip ji vykdyti, retai susiedami juos su platesniu ir išbandytu teoriniu pagrindu. Pradedant nuo atsisakymo vykstanti konfliktą pripažinti karu ir baigiant jo globalaus masto pasekmių nesuvokimu, šio karo priešakinėse linijose esantys strategai prarado nemažai laiko, kol buvo iš naujo atrasta ir suvokta klasikinès sukilimo ir kontrsukilimo teorijos bei jos šiuolaikinių atmainų vertè. Tai, ką jau pripratome traktuoti tik kaip siekį užkirsti kelią tolesniems teroro išpuoliams, reikia traktuoti kaip „politinį karą" įvaizdžiu ir idëjų dimensijoje, kur svarbiausia yra musulmonu pasaulio auditorija ir kur smurtas pasitelkiamas kaip jos nuomonės formavimo poveikio ir mobilizavimo priemonè. Tai, kad šio smurto pagrindinis taikinys yra tarptautinės sistemos hegemonas ir dabartinès pasaulio tvarkos palaikytojas, būtent Jungtinès Valstijos, bei jas palaikančios valstybès ir visuomenès, paverčia ši karą iš tikruju pasauliniu karu. Kaip ir tai, kad Al Qaedos darbotvarkè ir politinės mobilizacijos arealas peržengia daugelio valstybių sienas. Dèl globalaus masto ir kovojančiu pusiu pobūdžio gali kilti sunkumų absoliučiai tiksliai pritaikant klasikinę sukilimo ir kontrsukilimo teoriją tarptautinès sistemos lygiu, bet konflikto strategija nepriekaištingai parengta pagal sukilimo ir kontrsukilimo teriją. Šiame kare ginkluota jẻga vaidina daug mažesnị vaidmenị nei ịprastiniame ginkluotame konflikte. Kovojančiuose tinkluose - Al Qaeda ir JAV vadovaujamoje koalicijoje - informacija, propoganda, politiniai, socialiniai ir kultūriniai ryšiai reiškia daug daugiau nei kariné jejga. Kaip ir visi pasauliniai karai (Pirmasis, Antrasis ir Šaltasis), jis, be jokios abejonès, gali pakeisti pasaulio tvarką, kaip kad sukilimai sugeba pakeisti politinę tvarką valstybiu viduje. Galbūt globalus Al Qaedos sukilimas, spaudžiamas ryžtingo, ilgam konfliktui pasirengusio ir iš savo klaidu besimokančio kontrsukilèlio, galiausiai išsikvèps, kaip kad nutinka daugumai sukilimu valstybiu viduje. Tačiau lygiai taip pat egzistuoja galimybè, kad Al Qaedos sukilimas taps tuo katalizatoriumi, kuris prives prie Pax Americana žlugimo. Tikriausiai tam reikès ir daugiau „ingredientų“ -Kinijos galybės augimo, Rusijos oponavimo JAV politikai stiprëjimo, gilios ekonominès ar finansinès krizès pačiose JAV, ju technologinio dominavimo susilpnëjimo ar panašiu veiksnių, bet lygiai taip pat valstybiu politinius režimus sukilimai ilgainiui sužlugdydavo dèl tų režimų silpnų vietų ir netobulumų. JAV, nors ir lètai suvokusios, kas vyksta, jau pasitelkè sukilimo ir kontrsukilimo teorijos paaiškinimus savo strategijoje ir net pabandè sukonstruoti ideologinę alternatyvą Al Qaedos siekiams diskredituoti ir neutralizuoti. Tačiau vis dar nėra suvokimo, kad užsienio ir saugumo politikoje JAV negali sau daugiau leisti nekoordinuotu, tik į atskirus regionus ar valstybes nukreiptu, fragmentuotu, nenuosekliu veiksmų ar iniciatyvų. Tokiame kare, kurį kariauja Amerika ir jos sajungininkai, įvairių krypčių nekoordinuotumas ir nesubordinuotumas globalaus kontrsukilimo strategijai turès liūdną pasekmę. Kokios tos pasekmės bebūtu, mes jų neišvysime dar ilgai. Sukilimas ir kontrsukilimas yra ilgas karas, o laikas paprastai būna sukilèliu sajungininkas. Viena aišku - jam pasibaigus, pasaulis gali atrodyti visai kitoks nei dabar. 